\title{
RUBIERA CANCELAS, CARLA. LA ESCLAVITUD FEMENINA EN LA ROMA ANTIGUA. FAMULAE, ANCILLAE ET SERUAE (COLECCIÓN DEMÉTER). OVIEDO: EDICIONES TRABE, 2014. 302 p. ISBN: 978-84-8053-777-3
}

\author{
Filipe N. Silva ${ }^{1}$
}

Writing at a time when the debt bondage (nexum) no longer existed, the Roman jurist Marcianus, in a well-known quote recorded in Digest (D. I.5.5), explained that slaves were the defeated enemies or "those who were born from our slave-women" (ex ancillis nostris nascuntur). Like war, the biological reproduction was also recognized as a genuine reason for enslavement. In Roman society, where the transmission of serfdom was conceived under a matrilineal pattern Patterson, 1982: 139), we may infer that men and women experienced the slavery in different ways. This difference, however, cannot be understood only from the theme of biological reproduction.

Admitting that the Roman slave-women were under a double standard of submission (due to their social position of slave and women), Carla Rubiera Cancelas' opportune book, La esclavitud femenina en la Roma Antigua (2014), offers a detailed synthesis of women's slavery in Ancient Rome. Based on literary and legal texts, but also using the epigraphic and iconographic evidence as its main sources, Rubiera Cancelas' study is divided in five chapters. In its first chapter, the book presents a historiographic course about the History of Roman Women. Despite some exceptions, historical interest on feminine slavery in Ancient Rome, as demonstrated by authors, was late in modern historiography.

Named El uso de las fuentes, the second chapter claims for a critical view on ancient sources. Rubiera Cancelas (2014) points out that Roman literary and legal texts about slavery were written by privileged men: their writings, thus, exposes a misogynistic and pro-slavery opinion (p.47-48). Epigraphy, in this case, is a rich alternative to a less biased historical testimony about the Roman enslaved women.

The third chapter explains the textual and iconographic images of Roman slaves. Through an analysis of the barbaric features of slaves portrayed in

1 PhD Student. State University of Campinas, São Paulo, Brazil. E-mail: filipe.hadrian@gmail.com

Heródoto, Unifesp, Guarulhos, v.4, n.1 - 2019.1. p. 425-426

DOI: 10.34024/herodoto.2019.v4.10131 
Roman war trophies and monuments, the Spanish historian reiterates the outsider status attributed to slaves in this society. Influenced by gender and postcolonial theories under the encouragement of Gayatri Spivak's essay Can the subaltern speak?, Rubiera Cancelas (2014. p.115-117) also recognizes the subalternity of Roman women-slaves because they were silenced in ancient texts.

The daily work of Roman enslaved-women is the main theme of the fourth chapter, named Trabajadoras esclavas en la ciudad de Roma. Based on epigraphic evidence, the author rejects the well-known hypothesis of feminine domestic confinement and, instead, describes the multiple occupations of seruae and ancillae in ancient Rome. In addition to the female slave work in textile activities, medicine, teaching, breastfeed and prostitution, the arts, dance and public spectacles were also performed by Roman slave-women and freedwomen.

The fifth chapter examines the theme of biological reproduction of ancient slavery. On the one hand, Rubiera Cancelas (2014) finds that ancient Roman writers circumscribe the slave-women to the role of " $(.$.$) mothers at$ the service of an economic and social system that explores them" (Rubiera Cancelas, 2014: 249). On the other hand, however, the author examines the kinship ties built by these women in order to overcome the social death installed by the slavery.

Provided with a consistent historical and archaeological research, Carla Cancela's book demonstrates how conservative and traditional ancient history can respond satisfactorily to the social present-days anxieties. By revealing the arbitrariness of moral judgement about the Roman enslavedwomen, and by denouncing the silence applied to these women in ancient texts, the author invites us to a permanent reflection on the proximity between power, knowledge and social exclusion. The use of modern gender theories, as demonstrated in La esclavitud femenina en la Roma Antigua, compels us to rethink old and modern slavery regimes from a new and profitable perspective.

\section{Reference}

PATTERSON, Orlando. Slavery and social death. A comparative study. Harvard: University Press, 1982. 